\title{
The Implementation of Socialization, Externalization, Combination, and Internalization (SECI) Through EDMODO Application to Improve Student Group's Learning Outcomes
}

\author{
A.B. Prasetya ${ }^{\mathrm{a}}, \mathrm{K}$. Taroreh ${ }^{\mathrm{b}}$ \\ ${ }^{a}$ Universitas Bina Nusantara, Jakarta, Indonesia \\ ${ }^{\mathrm{b}}$ Universitas Pelita Harapan, Tangerang, Indonesia
}

\begin{abstract}
The purpose of this study is to implement SECI through EDMODO in classroom learning as well as to improve student group's learning outcomes in terms of their cognitive, affective, and psychomotor domains. This study utilized an application program named EDMODO as an assisting media in the process of SECI implementation. In addition, this study was done through classroom action research method conducted in three cycles, each of which consisted of two meetings. Each cycle applied the stages of SECI and used EDMODO as well. The data of this research was collected from observation, peer feedback, reflection journal, and tests. All the data were analyzed in descriptive qualitative way. The result of this study indicated that the SECI model using EDMODO has been successfully applied for the learning process in the classroom. Moreover, it improved students' learning outcomes in terms of cognitive, affective, and psychomotor domains for every students in the group.
\end{abstract}

Keywords-Socialization, EDMODO Application

\section{INTRODUCTION}

Learning is an acquisition of knowledge or skills through stories, experiences, observations, and so on. The success of learning process can be observed from the learning achievement accomplished by the students.

Gottschalk (2005, 95) said that knowledge transfer takes place at a variety of levels within the organization including the transfer of knowledge between individuals, from individuals to the source of explicit knowledge, from individual to group, between groups, in group transfers, and from group transfers to organizations. The concept of SECI (Socialization, Externalization, Combination, and Internalization) is an appropriate constructive theory of transferring knowledge to help students understand the new concepts of certain subjects so that they can achieve the expected standardized learning outcome.

The use of this web technology in an educational program which provides support for teachers to achieve the pedagogical goals of the students, to organize the course content, and to support the students' learning devices at the end (Cigdemoglu, $\mathrm{dkk}, 2011,790)$. EDMODO is an application specifically designed for learning activities. Kruger \& Bester $(2014,61)$ stat- ed that EDMODO can be used by teachers to communicate with their students, share information, post assignments and perform assessments. EDMODO is a learning management system which is able to facilitate teachers to conduct and manage the process of learning in the class without any difficulty (Kandappan, 2014, 2).

This research refers to the learning process in $7^{\text {th }}$ grade of SMP (Junior High School) X in Jakarta where most of the students have difficulties to achieve the determined learning outcomes, especially in Chemistry. When a test was conducted for several previous lessons of Chemistry, most of the students did not achieve the determined learning outcomes. Only few of them had reached the standard learning outcome. When the assessment to know the students' learning achievement was carried out, a phenomenon was discovered in which most of the students performed less satisfied learning achievement. Therefore, the researcher needs to study further the phenomenon of the student learning outcomes by analyzing whether knowledge transfer and conversion understood by the students can improve the result of group learning outcomes [4]. In conducting this research, there are several questions seeking for the answers: 1) How can SECI and EDMODO be implemented in the process of learning in class? 2) How can the implementation of SECI through EDMODO improve the group learning outcomes in three domains of cognitive, affective and psychomotor aspects? 3) How to overcome obstacles that arise in the process of implementing SECI through EDMODO so that the group learning outcomes in cognitive, affective and psychomotor domains can be improved?

\section{METHOD}

\section{A. Research Subject}

This classroom action research involved 16 students of 7B Class with age range $11-12$ years old. The subjects were 7B Class consisting of 8 male students and 8 female students. This action research was carried out on one of the Science subjects, Chemistry in SMP (Junior High School) Mahabodhi Vidya. 


\section{B. Research Design and Procedure}

The action research was conducted based on the research model proposed by Kemmis and Mc Taggart. The researcher has designed 3 cycles for the research.

\section{TABLE I.}

1. Socialization (Affective)

In this stage, the students discuss the theory of Acids and Bases at first. Then, each leader of the groups uploads the teaching materials in each edmodo group. A discussion is conducted in edmodo group afterwards. At the first meeting, in the class, the students study as usual by learning about the theory of Acids and Bases. The teaching and learning activities take place normally. In doing guided exercises, the teacher asks students to solve problems by carrying out a group discussion in class. The students can also seek for the answers by making use of their books and the internet.

3. Combination (Psychomotor and

\section{Affective)}

At this meeting, the students carry out an experiment concerning learning materials which have been discussed through EDMODO; that is about Acids and Bases. Then, the students perform an experiment to identify the acid solution and alkaline solution using the natural indicators. Following the experiment, the students are asked to answer some questions related to the result of the experiment that are listed in the experiment procedure.

\section{TABLE II.}

\section{CyCle Design 2}

1. Socialization (Affective)

At this stage, the students are asked to hold a discussion in edmodo group respectively dealing with the topic of measuring the $\mathrm{pH}$ scale that has been explained by the teacher in the first meeting using lecturing method and presentation. Furthermore, the students are asked to answer questions about measuring $\mathrm{pH}$ scale by conducting a group discussion.

3. Combination (Psychomotor and Affective)

At this stage, the students will carry out an experiment on measuring $\mathrm{pH}$ scale. The teacher prepares and introduces the equipment and materials that are going to be used in the experiment. The experiment is guided by sheets of procedure distributed in each group, and the students are asked to answer the questions regarding to the experi-

CYCLE DESIGN 1

2. Externalization (Affective)

After holding discussions and learning activities at the first meeting, the teacher asks each leader of the groups to actualize the result of the discussion in the form of a summary. Each leader of the groups is asked to upload the discussion result in the respective group.

\section{Internalization (Cognitive and} Psychomotor)

The internalization stage takes place in the second meeting. After carrying out activities in the laboratory, the students are asked to go back to the class and be ready for quiz. The evaluation in the form of a quiz is carried out to measure the learning achievement of each student in their respective group after the learning activities conducted involving the implementation of SECI through EDMODO.

\section{Externalization (Affective)}

After holding a discussion and learning activities at the first meeting, the teacher asks each leader of the groups to actualize the discussion result in form of a summary. The summary then is uploaded in the respective group so that the students can learn the main material of measuring the $\mathrm{pH}$ scale.

\section{Internalization (Cognitive and Psychomotor)}

The internalization stage takes place after the experiment has finished. The students are asked to go back to class and to answer the quiz distributed by the teacher. This activity is carried out to find out whether there is an improvement of the student learning outcomes in the second cycle.

ment that has been reported in the form of written text on the last part of the procedural sheets.

\section{TABLE III. CYCLE DESIGN 3}

1. Socialization (Affective) At the stage of socialization, each leader of the groups is asked to upload the presentation material that has been sent by the teacher, to EDMODO. Then, the students hold a discussion in the presentation column provided in each group. The topic discussed is about neutralizing solutions. At the first meeting, the students are also involved in learning activities in class as usual. The teacher uses interactive lecturing method and presentation to explain the neutralizing issue to the students.

\section{Combination (Affective and} Psychomotor)

The combination stage is conducted in the second meeting. At this stage, the students will carry out an experiment in Science Laboratory. The experiment deals with titration solutions. Before performing the experiment, the students, along with the teachers, identify the equipment and substances that are going to be analyzed.

\section{Research Instruments}

The research was carried out using several instruments, including: 1) observation sheet, 2) reflective journal, and 3) quiz. In the process of SECI implementation, the researcher used the observation sheet, interview, and reflective journal. Furthermore, the researcher used quiz as an instrument to measure the student learning outcomes.

\section{RESULTS AND DISCUSSION}

\section{A. Cognitive}

The cognitive domain is related to the activities in the human brain in the process of learning, i.e. the ability of an individual to think. Sudjana $(2015,22)$ sharpened the previous statement by stating that the cognitive domain which relates to intellectual learning outcomes, consists of six aspects. Those aspects are knowledge or remembrance, understanding, application, analysis, synthesis, and evaluation. According to Purwanto $(2010,50)$ cognitive learning outcome is a behavior change in cognitive domain. Cognitive learning outcome is not a single capability but more on the capability which cause changes in behavior in a cognitive domain covering several stages of phases [5].

The research shows that the process in the stages of socialization, externalization, and combination in every cycle 
was positively getting better from one stage to the next stage. In the socialization phase, the students conducted a more active and purposeful discussion. So, the positive impacts could be observed in the externalization phase. As a result, the summary of the discussion was excellent and it helps the students a lot.

The experiment process dealing with the combination phase was carried out well. The students were able to conduct the experiment well indicated by achieving the expected results. The success of these three phases supports the maximum cognitive learning outcomes in the internalization phase. The evaluation result or the test result indicated a significantly positive increase. The students' learning outcomes in a group has reached the standard expected by the researcher. The following is a diagram that compares the cognitive learning outcomes of Cycle 1, Cycle 2, and Cycle 3.

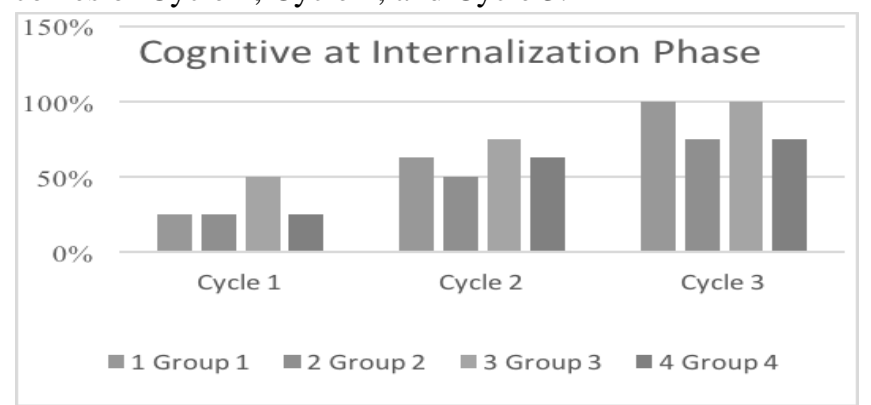

Fig 1. Students' Cognitive Learning Outcomes in the Internalization Phase

\section{B. Affective}

The affective domain relates to attitude and value of each individual. For each individual, a good cognitive aspect she/he has, will affect the attitude of the individual. According to Widoyoko $(2016,48)$, positive attitude will lead to positive behaviors, while negative attitude will lead to negative behaviors. Furthermore, according to Siregar and Nara (2010, 155), attitude is a positive or negative tendency of an identity towards a certain psychological object. In addition, Sudjana $(2015,22)$ has divided the affective domain dealing with attitude into five aspects. They are acceptance, answer or reaction, evaluation, organization, and internalization.

This research indicated that the students' affective learning outcomes increased positively in every cycle. The active and purposive discussions emerged a discussion with good quality. The students were able to share tacit knowledge by giving comments while getting involved in the discussion. The positive result in socialization phase contributed to the positive impacts in the externalization phase. The tacit knowledge was well-demonstrated and well-constructed seen from the summary of each group. The summary was useful for the students because it was an explicit knowledge actualized through an experiment in the combination phase. The experiment process was successfully conducted and it obtained the intended result.
Most of the students were able to answer correctly the questions on the tests given. Moreover, the students' results were satisfied. The following is a diagram to compare the affective learning outcomes in cycle 1 , cycle 2 , and cycle 3 in the socialization and externalization phases.
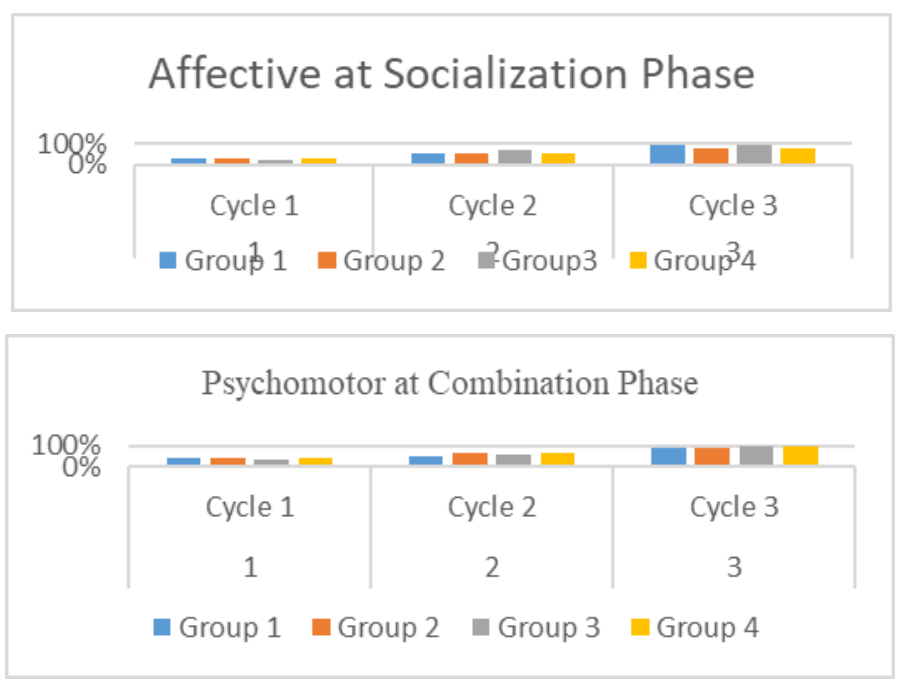

Fig 2. Students' Affective Learning Outcomes in the Externalization Phase

\section{Psychomotor}

According to Sudjana $(2015,22)$, a psychomotor domain concerns with the learning outcomes which are related to the skills and ability to take actions.

In this research, it was revealed that the students learning outcomes in terms of the psychomotor domain in combination phase in Cycle 1, 2, and 3 improved positively. The knowledge acquired by the students in the socialization and externalization phases helped the students to perform the experiment in the laboratory. The experiment was well and effectively conducted in which all groups were successful with their experiments and the results were in accordance with the hypothesis. The following is a diagram comparing the results of the psychomotor aspects in Cycle 1, 2, and 3 at the Combination Phase.

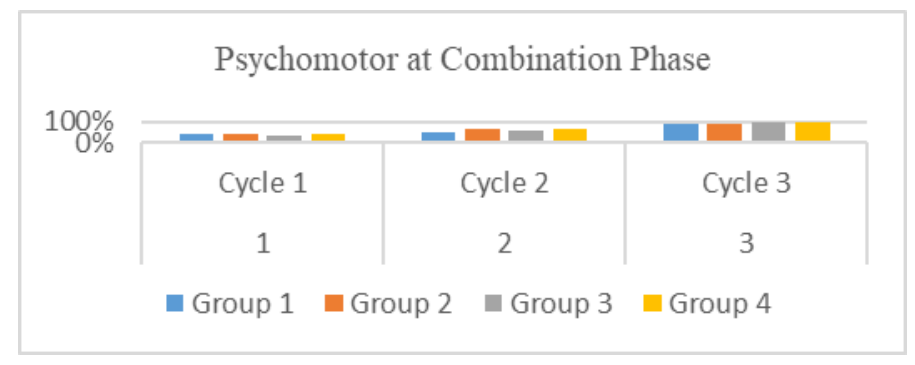

Fig 3. Students' Psychomotor Learning Outcomes in Combination Phase 


\section{CONCLUSION}

The result of this research indicated the following conclusions:

1. Based on the results obtained from an observation data collection instruments, it was found that the SECI process improved positively so that the researcher can draw conclusion that SECI has been successfully implemented the learning activities through EDMODO application.

2. Based on the results obtained in the Cycle 1, 2, and 3, the researcher found out that in the cognitive domain, the average scores of students' test results in groups within every cycle increased. Likewise, in the affective domain, the observation scores in groups in every cycle were increasing, and similarly, in the psychomotor domain, the observation score in each group in every cycle increased as well.

3. In conducting this research, the researcher faced some obstacles which included several important things:

a. The implementation of the Combination and Internalization phases were less successful when they were only conducted in one meeting.

b. After implementing the Combination phase, each group was not given adequate time to carry out discussion in order to understand more about the concept before going to the internalization phase.

To overcome all the obstacles mentioned above, some following actions can be taken:

c. It is suggested that the implementation of combination and internalization phases in the next research can be carried out on different days in order to maximize the process of each phase so that the students will focus more in doing the activities at each phase.

d. By dividing the meetings/sessions between the combination and internalization, the students will have more time to conduct discussions in the Combination phase. The discussions in the Combination phase are performed immediately after conducting the experiments so that the students will have understood first the concept from the experiment.

\section{REFERENCES}

[1] C. Cigdemoglu, H. O. Arslan, and H. Akay, "A Phenomenological Study of Instructors' Experiences on an Open Source Learning Management System", Procedia Social and Behavioral Sciences, pp. 790-795, 2011

[2] Gottschalk, Petter. Strategic Knowledge Management Technology. United Stated of America: Idea Group Publishing, 2005.

[3] B. Kandappan, A Study on „Student Preference Towards the Use of EDMODO as a Learning Plattform to Create Responsible Learning Environment. 416 - 422. USA: Procedia, 2014.

[4] Kruger, M. \& Bester, R, "Mobile Learning: A Kaleidoscope," Electronic Journal of e-Learning, vol. 12, no. 1, pp. 61. 2014.
[5] McInerney, Claire, "Knowledge Management and the dynamic nature of knowledge," Journal of the American Society for Information Science and technology, 1009 - 1018, 2002.

[6] Purwanto, Evaluasi Hasil Belajar. Yogyakarta: Pustaka Belajar, 2010.

[7] E. Siregar and N. Hartini, Teori belajar dan pembelajaran, Bogor: Ghalia Indonesia, 2010.

[8] N. Sudjana, Penilaian Hasil Proses Belajar Mengajar, Bandung: PT Remaja Rosdakarya, 2015.

[9] S.E.P. Widoyoko, Penilaian Hasil Belajar di Sekolah, Yogyakarta: Pustaka Pelajar, 2016. 